\title{
Animal model for training in sentinel lymph node biopsy of the stomach through combined methods ${ }^{1}$
}

\author{
Modelo animal para treinamento em pesquisa de linfonodo \\ sentinela em estômago mediante métodos combinados
}

\author{
José Roberto Alvesi, Luiz Roberto Lopes ${ }^{I I}$, Luciana Rodrigues de Meirelles ${ }^{\text {III }}$, Celso Darío Ramos ${ }^{\text {IV }}$, Tânia Sasasakiv , Nelson \\ Adami Andreollovi \\ IFellow PhD degree in Surgery Sciences, UNICAMP, Campinas-SP, Brazil. Main author. Conception, design, collection and interpretation of data; \\ surgical procedures; statistical analysis; manuscript preparation; responsible for English language. \\ IPhD, Full Professor, Digestive Surgery, School of Medical Sciences, UNICAMP, Campinas-SP, Brazil. Advisor, responsible for substantive scientific \\ and intellectual contributions to the study, manuscript writing, critical revision. \\ IIIPhD, Department of Pathology, School of Medical Sciences, UNICAMP, Campinas-SP, Brazil. Responsible for histological examinations.

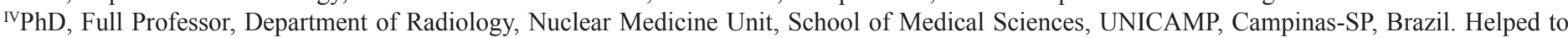 \\ determine and write the study methodology, provided technical advice on the handling of the radioactive substances and gamma probe. \\ ${ }^{\vee}$ MD, Resident, Nuclear Medicine, School of Medical Sciences, UNICAMP, Campinas-SP, Brazil. Assisted in handling the gamma probe. \\ ${ }^{\mathrm{V}} \mathrm{PhD}$, Chairman and Head, Digestive Surgery, School of Medical Sciences, UNICAMP, Campinas-SP, Brazil. Critical revision.
}

\begin{abstract}
PURPOSE: Create and validate a proposed animal model for training in sentinel lymph node biopsy of the stomach.

METHODS: In thirty-two rabbits, through a laparotomy, they received a subserosal injection of $0.1 \mathrm{ml}$ of phytate labeled with technetium-99m $(0.2 \mathrm{mCi})$ in the anterior wall of the gastric corpus, followed by $0.2 \mathrm{ml}$ of Blue Patent $\mathrm{V}^{\circledR} 2.5 \%$, through the same puncture site. Suspicious lymph nodes were searched in vivo at five, ten and 20 minutes, both visually (Blue Patent stained lymph nodes) and with a manual gamma radiation detector (to detect suspected radioactive lymph nodes). After 20 minutes, was performed resection of these for further evaluation of radioactivity (ex vivo) and histological study.

RESULTS: Lymph nodes were identified in 30 rabbits (Average of 2.2 lymph nodes per animal). Of the 90 suspected lymph nodes that occurred in the study, 70 cases $(77.8 \%)$ were histologically confirmed for lymphoid tissue. Of these, the majority were located in the periesophageal region of the gastric fundus. The sample presented a mortality rate of $6.25 \%$ and nine complications related to the method, which interfered in the identification of the lymph nodes.

CONCLUSION: The animal model for sentinel node biopsy in rabbit stomachs proved to be feasible, with low complexity and reproduced the difficulties encountered for gastric lymph node biopsy in humans, being adequate for surgical training.
\end{abstract}

Key words: Models, Animal. Sentinel Lymph Node Biopsy. Stomach. Coloring Agents. Technetium. Rabbits.

\section{RESUMO}

OBJETIVO: Criar e validar uma proposta de modelo animal para o treinamento em pesquisa de linfonodos sentinelas no estômago.

MÉTODOS: Em trinta e dois coelhos, mediante laparotomia, foi injetado na subserosa da parede anterior do corpo gástrico, 0,1 ml de fitato marcado com tecnécio- $99 \mathrm{~m}(0,2 \mathrm{mCi})$, seguido pelo mesmo orifício, de 0,2 ml de Azul Patente $\mathrm{V}^{\circledR} 2,5 \%$. A cavidade abdominal foi avaliada, in vivo, por meio de inspeção para pesquisa de suspeitas de linfonodos azuis e com detector manual de radiação gamma aos cinco, dez e 20 minutos para pesquisa de suspeitas de linfonodos radioativas. Após 20 minutos, foi realizada a ressecção dessas para posterior avaliação da radioactividade (ex vivo) e estudo histológico.

RESULTADOS: Foram identificados linfonodos em 30 coelhos (Média de 2,2 linfonodos por animal). Das 90 suspeitas de linfonodos ocorridas no estudo, em 70 casos $(77,8 \%)$ obteve-se confirmação histológica para tecido linfóide. Destas, a maioria estava localizada na região periesofágica do fundo gástrico. A amostra apresentou taxa de mortalidade de 6,25\% e nove intercorrências relacionadas ao método, que interferiram na identificação dos linfonodos.

CONCLUSÃO: O modelo animal para pesquisa de linfonodos sentinelas em estômago de coelhos mostrou-se factível, pouco complexo e reproduziu as dificuldades encontradas para a pesquisa de linfonodos gástricos em humanos, sendo adequado para o treinamento cirúrgico.

Descritores: Modelos Animais. Biópsia de Linfonodo Sentinela. Estômago. Corantes. Tecnécio. Coelhos. 


\section{Introduction}

Through studies carried out by Gould et al. ${ }^{1}$, Cabanas $^{2}$, Morton et $\mathrm{al}^{3}{ }^{3}$, we have the basis of the concept of sentinel lymph node biopsy (SLNB).

After the consolidation of SLNB in cancers of the skin ${ }^{3-}$ ${ }^{5}$ and breast ${ }^{5-7}$, lymphadenectomies related to surgeries for the treatment of these neoplasms have become selective, and are no longer routine, resulting in a decrease in morbidity and mortality rates. In the last decade, SLNB has also been carried out for cases of early gastric cancer ${ }^{5,8-27}$.

The initiatives to perform SLNB in early gastric cancer are justified by the less invasive procedures (smaller gastrectomies and the use of videolaparoscopic access), less extensive lymphadenecomies (D1), with consequent preservation of gastric function, better esthetic appearance, less morbidity and mortality, and better quality of life after surgery, without jeopardizing the oncological safety of the treatment and survival of these patients $^{19,24,28}$.

However, the stomach has characteristics that make SLNB difficult, such as the existence of a multi-directional lymphatic drainage system, the presence of skip metastasis ${ }^{9-11}$ and an average identification of sentinel nodes of more than two per individual ${ }^{5,9,16,12-15}$

Fundamental, following the studies of Claude Bernard (1865), the Nuremberg Cod (1947) and the Helsinki Declaration (1975), it is advisable that experiments on human beings only be carried out based on evidence from research on animals ${ }^{29-31}$.

There have been only a few publications related to the creation of an experimental animal model for SLNB of the stomach, using experiments on swine ${ }^{32}, \operatorname{dogs}^{33}$ and rabbits ${ }^{34}$. However, they have limitations, such as their small sample size ${ }^{9,11}$, high cost, and large sentimental humanistic appeal, especially when dogs are involved. Also, for the establishment of an experimental model, it is necessary to take into consideration the characteristics of the animal and its similarities to humans $29-31,35$.

Even after careful review of the literature, based on the databases: Medline; Lilacs; ScieLo; Cochrane BVS, no anatomical description of the gastric lymph node in rabbits could be found ${ }^{36}$, and the same applies to its comparison with humans.

All that is found is the description of the dimensions of the rabbit stomach, which are similar to that of a human infant ${ }^{37}$, and a description of the gastric wall of the animal, which is thinner, especially in the regions of the body and fundus $s^{35,37,38}$, with the occurrence of stratification of this gastric wall in layers (submucosal, muscle proper and serosa) $)^{37-39}$, consisting of a three- dimensional lymphatic plexus that interconnects them, without any apparent differences in terms of their distribution in the stomach ${ }^{36}$.

This study aims to develop an appropriate experimental animal model for training in gastric lymph node biopsy, through the use of a radiolabeled colloid ( $\mathrm{RC})$, associated with the handling of hand-held gamma probe.

\section{Methods}

Thirty-two healthy, male rabbits (Oryctolagus cuniculus) of the New Zealand breed, aged between 3.0 and 5.5 months (average 4.6 months) with body weights of between 3000 and 4200 grams (average 3407.8 grams), were submitted to intramuscular anesthesia with ketamine hydrochloride $(30 \mathrm{mg} / \mathrm{Kg})$ and xyaline hydrochloride $(3 \mathrm{mg} / \mathrm{Kg})$, and local infiltration of the abdominal wall with $10 \mathrm{ml}$ of $1 \%$ lidocaine.

The animals were then tied in position, in decubitus dorsal, on the surgical table.

\section{Lymph node biopsy}

Following middle xiphotransumbilical laparotomy, the presence of radioactivity was evaluated inside the abdominal cavity, using a hand-held gamma probe $\left(\right.$ Europrobe $\left.^{\odot}\right)$, i.e. the initial background (BG).

Next, the subserosa of the gastric wall was injected at point $\mathrm{X}(\mathrm{PX})$, using a 26-guage needle, $0.1 \mathrm{ml}$ of $\mathrm{RC}$ consisting of phytate colloid marked with radioisotope tecnécio-99m at 0.2 $\mathrm{mCi}$, followed by $2 \mathrm{ml}$ of 2,5\% Patent Blue dye Guerbet ${ }^{\circledR}(\mathrm{AzP})$, injected by the same orifice, pressing lightly on the site for 5 minutes. PX was determined on the anterior wall of the gastric body, $3.5 \mathrm{~cm}$ from the small curvature in the region between the two anterior branches of the left gastric artery.

For the biopsies, a needle was introduced $0.5 \mathrm{~cm}$ into the subserosal layer (Figure 1).

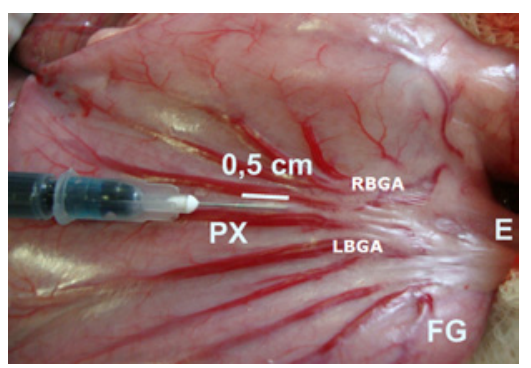

FIGURE 1 - Injection (with AzP) in Point X (PX), in the subserosa of the gastric wall. E. Esophagus; FG. Gastric Fundus; LBGA. Anterior left branch of the left gastric artery; RBGA. Anterior right branch of the left gastric artery. 
After five, ten and 20 minutes of $\mathrm{RC}$ and $\mathrm{AzP}$ injection, the "in vivo" evaluation of radioactivity inside the abdominal cavity was repeated, using the hand-held gamma probe (gamma probe), to look for suspect lymph nodes (SL).

The "in vivo" evaluation was carried out by visual identification of the lymphatic ducts originating from the injection and possible lymph nodes stained by AzP, as well as through evaluation, with a gamma probe, of the presence of radioactivity in these points, known as SL (Figure 2).

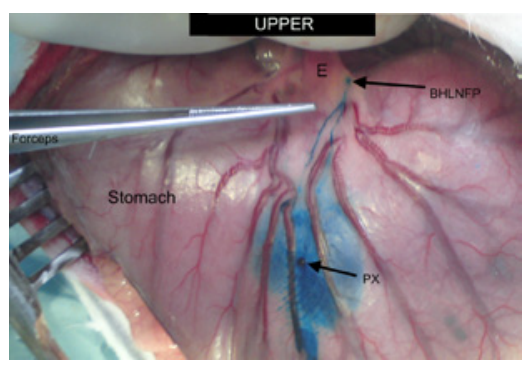

FIGURE 2 - Evaluation of the abdominal cavity at ten minutes, demonstrating the presence of a suspected blue-radioactive lymph node (BHLNFP), subsequently confirmed histologically as lymphoid tissue. In the photo we have a pincer pointing to a lymphatic duct stained in blue. E. Esophagus; PX. Point X; BHLNFP. Blue-hot lymph node gastric-fundic periesophageal.

The SL were classified as: blue only (dyed and monitored for inferior radioactivity ten times that of the initial or final BG); radioactive only (not dyed, but with radioactivity count higher than ten times that of the initial or final BG, and radioactive blue (both conditions present). They were then sub classified by anatomical localization (Table 1). Observation: The final BG consists of the radioactivity count emitted by the interior of the abdominal cavity after exeresis of the organs.

After the last evaluation at 20 min with the gamma probe, dissection of the SL was performed, associated with total gastrectomy and splenectomy, according to the standard technique ${ }^{35}$.

Euthanasia was performed by increasing the anesthesia with $25 \mathrm{mg} / \mathrm{ml}$ Sodium Thiopental overdose and subsequent injection with $10 \mathrm{ml}$ of $19.1 \%$ potassium chloride.

Finally, the radioactivity presented by the same structures as those evaluated in vivo was evaluated ex vivo, along with the gastric content.

Observation: The purchase cost of the animals was recorded.

\section{Histological confirmation study}

The resected SL, duly identified, were fixed in $10 \%$ formaline buffer for at least 12 hours. They were then embedded in paraffin, cut to a thickness of $6 \mu \mathrm{m}$ and stained with hematoxilineosin, to confirm the presence of absence of lymphoid tissue.

This study is part of a project approved by the Ethics Committee on the use of Animals of the State University of Campinas - SP, under protocol n ${ }^{\circ}$. 2033-1.

\section{Statistical analysis}

The variables of analysis were compared, using the statistical tool ANOVA for repeated measurements.

The transformation by ranks was applied to the means, due to the variably, and for comparison of these the Wilcoxon test was used for related samples.

To determine the agreement between the methods, the interclass correlation coefficient (ICC) was used ${ }^{40}$.

The level of statistical significance adopted in this study was $\mathrm{p}<0.05$.

\section{Results}

In 32 animals studied through the combined SLNB methods, 90 SL were identified, obtaining histological confirmation of lymphoid tissue in 70 cases (Table 1).

TABLE 1 - Distribution of 70 lymph nodes by location and classification according to SLNB method.

\begin{tabular}{|c|c|c|c|c|}
\hline LYMPH NODE LOCATION & $\begin{array}{l}\text { Blue } \\
\text { only }\end{array}$ & $\begin{array}{c}\text { Radioactive } \\
\text { Only }\end{array}$ & $\begin{array}{c}\text { Blue- } \\
\text { Radioactive }\end{array}$ & $\begin{array}{c}\text { TOTAL } \\
(\%)\end{array}$ \\
\hline \multicolumn{5}{|l|}{$\begin{array}{l}\text { Group of perigastric } \\
\text { lymph nodes: }\end{array}$} \\
\hline $\begin{array}{l}\text { Between the } \\
\text { stomach and the } \\
\text { gastric fundus }\end{array}$ & 1 & 1 & 21 & $\begin{array}{l}23 \\
(32.86 \%)\end{array}$ \\
\hline Along the small curvature & 6 & 0 & 7 & $\begin{array}{c}13 \\
(18.57 \%)\end{array}$ \\
\hline $\begin{array}{l}\text { Periesophageal next to } \\
\text { the small gastric curvature }\end{array}$ & 4 & 1 & 7 & $(17.14 \%)$ \\
\hline $\begin{array}{l}\text { Anterior to the } \\
\text { gastric fundus }\end{array}$ & 1 & 2 & 2 & $\begin{array}{l}5 \\
(7.14 \%)\end{array}$ \\
\hline $\begin{array}{l}\text { Anterior to the } \\
\text { gastric fundus }\end{array}$ & 2 & 0 & 3 & $\left.\begin{array}{l}5 \\
(7.14\end{array}\right)$ \\
\hline \multicolumn{5}{|l|}{$\begin{array}{l}\text { Group of lymph nodes } \\
\text { further from the stomach: }\end{array}$} \\
\hline Next to the vena cava & 3 & 0 & 3 & $(8.57 \%)$ \\
\hline Next to the pancreas & 0 & 0 & 4 & $\stackrel{4}{(5.72} \%)$ \\
\hline \multirow[t]{2}{*}{ Retroesophageal } & 0 & 0 & 2 & $\stackrel{2}{(2.86 \%)}$ \\
\hline & 17 & 4 & 49 & $\begin{array}{c}70 \\
(100 \%)\end{array}$ \\
\hline
\end{tabular}

Note: No SL were found along the greater curvature of the stomach. Lymph nodes were identified in 30 animals (93.75\%), with an average of 2.2 per animal (Table 2). 
TABLE 2 - Results of sentinel node detection according to the method used.

\begin{tabular}{|c|c|c|c|}
\hline & $\mathbf{L N}$ & detection & method \\
\hline Variables & Dye & Isotope & Combination \\
\hline $\begin{array}{c}\mathrm{N}^{\circ} \text {. animals in who } \\
\mathrm{LN} \text { were identified } \\
(\%)\end{array}$ & $30(93.75 \%)$ & $27(84.37 \%)$ & $30(93.75 \%)$ \\
\hline $\begin{array}{l}\text { Average of the } N^{0} \text {. of } \\
\text { LN identified by An } \\
\text { (SD+/-) }\end{array}$ & $2.06(1.39)$ & $1.66(1.31)$ & $2.19(1.35)$ \\
\hline Sensitivity (\%) & $66 / 70(94.3 \%)$ & $53 / 70(75.7 \%)$ & $70 / 70(100 \%)$ \\
\hline $\begin{array}{c}\text { Positive predictive } \\
\text { value (\%) }\end{array}$ & $66 / 86(76.7 \%)$ & $53 / 66(80.3 \%)$ & $70 / 90(77.7 \%)$ \\
\hline Accuracy (\%) & $66 / 90(73.3 \%)$ & $60 / 90(66.6 \%)$ & $70 / 90(77.7 \%)^{*}$ \\
\hline
\end{tabular}

Note: $\mathrm{N}^{\circ}$. $=$ Number of; $\mathrm{LN}=$ Lymph nodes; $\%=$ percentage, $\mathrm{SD}+/-=$ Standard deviation; An = Animal. *If only lymph nodes identified in the 10 minute evaluation are considered, we would have accuracy of the combined method of $40 / 54(74.07 \%)$

Of the 90 SL, 10 cases presented histological confirmation for more than one lymph node, i.e. in seven cases for the same suspicion, there was histological identification of two associated lymph nodes and in three cases, three associated lymph nodes were identified.

Two deaths occurred in the study (6.25\%). Of these, one occurred during the evaluation of the abdominal cavity at 10 minutes by overdose of anesthetics, and the other during dissection of a suspected paracaval lymph node by vascular lesion (Table 3 ). During the study, there were 20 complications, 14\% of which made SLNB unfeasible (Table 3).
Applying ICC to demonstrate the level of agreement between the suspicion generated by the SLNB methods and histological confirmation, for the evaluations carried out at 5, 10 and 20 minutes, higher levels of agreement were found for the radioactive only SL up to 10 minutes (ICC $=0.552$, with $\mathrm{IC} 95 \%$ $=0.188-0.770$ ) and blue only or blue-radioactive, at 20 minutes $(\mathrm{ICC}=0.524$, with IC95\% $=0.147-0.772)$. In relation to the two cases in which no lymph nodes were identified, one was in an animal that had suffered an accident due to loss of RC and AzP, which had spilled into the abdominal cavity, and the other case was related to the death that was caused by anesthetic overdose.

The sizes of the lymph nodes ranged from 0.3 to $6.0 \mathrm{~mm}$ (mean $=2.05 \mathrm{~mm}$ and SD $+/-1.30)$.

The mean radioactivity observed for the radioactive lymph nodes in vivo at times five, ten and 20 minutes was 170.7 cps (SD+/- 181.7), 174.6 cps (SD+/-204,5) and 254.7 (SD+/384.7), respectively. In the evaluation ex vivo, they presented mean radioactivity of $221.5 \mathrm{cps}(\mathrm{SD}+/-241.2)$.

As for the evaluation of radioactivity presented by the first lymph node identified, there was a statistically significant increase in this value over time, during evaluation in vivo at five ( $\mathrm{p}$ $=0.0004)$ and ten minutes $(\mathrm{p}=0.0023)$ when compared with the evaluation at 20 minutes.

The majority of the SL (60\%) and lymph nodes (57.1\%) were identified in the evaluation with the gamma probe in vivo up to $10 \mathrm{~min}$

The mean radioactivity of the gastric content related to the animals with absence of perforation of the gastric wall was

TABLE 3 - Intercorrences during the study, according to time of experiment.

\begin{tabular}{|c|c|c|c|c|c|c|}
\hline INTERCORRENCES & $\begin{array}{c}\text { During } \\
\text { Anesthesia } \\
\end{array}$ & $\mathbf{L P}$ & $\begin{array}{c}\text { Puncture } \\
\text { of the RC } \\
\text { AzP }\end{array}$ & $5 \mathrm{~min}$ & $10 \mathrm{~min}$ & $\begin{array}{c}\text { Dissection } \\
\text { LN }\end{array}$ \\
\hline \multicolumn{7}{|l|}{ DID NOT INLUENCE THE LYMPH NODE BIOPSY } \\
\hline Animal cried out* & 1 & & & & & \\
\hline Lesion of the sorosa of the gastric wall* & & 1 & & & & \\
\hline Pneumothorax & & 2 & & & & \\
\hline Small spread of the $\mathrm{RC} / \mathrm{AzP}$ at the puncture site & & & 5 & & & \\
\hline Leakage of teh $\mathrm{RC} / \mathrm{AzP}$ after pressing the site & & & & 1 & & \\
\hline Small hemorrhage during dissection of suspected & & & & & & \\
\hline paracaval lymph node & & & & & & 1 \\
\hline
\end{tabular}

\section{INFLUENCED THE LYMPH NODE BIOPSY A LITTLE}

Perforation of the gastric wall**

Major spreading of the $\mathrm{RC} / \mathrm{AzP}$ at the puncture site

3

JEPORDIZED THE LYMPH NODE BIOPSY

Death

Loss of RC/AzP with contamination of the abdominal

Wall

TOTAL

1

$1 \quad 3 \quad 12$

Note: $\mathrm{LP}=$ During laparotomy; $\mathrm{RC} / \mathrm{AzP}=$ Radiolabeled colloid and Patent Blue; LN = Lymph nodes; Min, minutes. *These occur in the same animal, and are related to causality, since the cries generate gastric distension, favoring the lesion of this organ during laparotomy; **In these three cases, gastric perforation was demonstrated after checking the mean quantity of radioactivity by the gastric content, respectively, $616 \mathrm{cps}, 460 \mathrm{cps}$ and $220 \mathrm{cps}$; cps, Number of counts per second of radcioactivity confirmed by the gamma probe (Europrobe ${ }^{\mathcal{C}}$ ) in five to ten seconds ${ }^{5}$. 
$2.15 \mathrm{cps}(\mathrm{SD}+/-2.45)$. The mean value exhibited by the initial BG of the whole sample was zero cps and that of the final BG was 6.87 cps (SD+/-15.01), ranging from 0 to 79.5 .

The cost of purchase of the animals was $\mathrm{R} \$ 12.00 / \mathrm{Kg}$.

\section{Discussion}

There have been initiatives that use SLNB in humans for gastric cancer aimed to indicating more economic lymphadenectomies and gastric resections ${ }^{15,18,19,24,25}$, and this conduct is currently becoming accepted in global clinical practice $^{9,11,26}$, especially after the recommendation of the Japanese multicenter trial on the use of SLNB in early gastric cancer (T1 or $\mathrm{T} 2, \mathrm{~N} 0, \mathrm{M} 0)^{27}$.

In the current study, even knowing that this animal model presented a stomach without neoplasia, this did not invalidate the objective of the study, since its aim was to demonstrate the complexity of anarchic gastric lymphatic drainage, showing the possibility of appropriate treatment for the identification of lymphatic ducts and lymph nodes in varied topographies, as well as the acquisition of the necessary skills for gastric wall biopsies and appropriate handling of the gamma probe.

In fact there are already specialists around the world carrying out SLNB on humans ${ }^{11,18,19,24,25,27,28}$, who can serve as sources for learning the technique, yet the presence of a feasible animal model would avoid possible ethical problems related to the training of new professionals, as well as the occurrence of errors related to the learning curve that could jeopardize the safety of the oncological treatment.

In this model, knowing that the learning curve for the use of SLNB is estimated in 30 cases $^{9,11}$, we considered it advisable to submit the professional executing this study, a trained surgeon, with no previous experience of the methods, to an equivalent sample size number, to adequately demonstrate its difficulties.

Despite the existence of other experimental animal models for SLNB in the stomach, in $\operatorname{dogs}^{33}$, pigs $^{32}$ and rabbits ${ }^{34}$, the model presented in this study had the following main advantages: low purchase cost of the animals, ease of handling, absence of the need for preoperative fasting, high animal replacement capacity (especially due to the short reproductive cycle), good adaptation to the laboratory environment, and limited humanistic sentimental appeal $^{30,31,35}$ (Chart 1). Moreover, it was the first national attempt that used rabbits ${ }^{32-34}$, presented an acceptable mortality rate and practicality in the execution of the exclusively intramuscular anesthesia, without the need for definitive intubation ${ }^{35}$.

Regarding the method chosen in this study, we used combined methods for SLNB ${ }^{5,9,18,20,21}$, through injection of RC and staining in the subserosa of the gastric wall ${ }^{13,23,26}$.

Due to the presence of a connection and free passage of the lymph of the lymphatic drainage system of the gastric wall, from the subserosal to the submucosal plexus, the injection site did not interfere in the results of the SLNB ${ }^{16}$. Furthermore, puncture in the subserosal region of the stomach wall is more practical, less technical, and faster to execute, and is ideal for use in individuals in training ${ }^{16}$.

Due to the absence of a similar theoretical basis, the choice of the injection point (PX) was based on the need for practicality in terms of access to and execution of the SLNB, as well as inferences obtained through the results achieved in a previous pilot study, involving nine rabbits, in which the researchers injected dye and $\mathrm{RC}$ at three points of the gastric body, and in which where PX was the point that presented identification of a higher number of lymph nodes.

The SLNB in this animal model presented a detection rate and average number of lymph nodes found per animal that were comparable with other studies on humans ${ }^{5,9,15,20,21}$.

It must be emphasized that the accuracy of the methods was influenced by the occurrence of $11 \%$ of SL that presented histological confirmation for more than one lymph node. Moreover, the sensitivity values presented in relation to the SLNB methods must be interpreted with care, since there was no neoplastic lesion in the present model.

In addition, due to the theoretical presence of lymph nodes in all the animals, it was not practicable to calculate the negative predictive value and specificity related to the methods.

However, these data revealed that the method with use of staining is more sensitive in this animal model, and supplements the evaluation carried out with the gamma probe $e^{5,21}$.

In this experiment the identification and classification of the blue and/or radioactive lymph node occurred just before and/or during exeresis of the organs, although this procedure is recommended before the gastrectomy, at varied times, according to the characteristics of the dye used ${ }^{5,10,12,15-17,21-23}$.

Nevertheless, the ideal time for evaluation in this model, based on the characteristics of the dye $\mathrm{e}^{5,9,11,14,22,23}$, anatomy ${ }^{35}$ and dimensions of the lymphatic drainage system of the animal's stomach $^{36}$, should probably be ten minutes after the injection of AzP.

It can also be noted that the evaluation carried out at five minutes did not present a statistically significant difference for the identification of lymph nodes by the methods used, when 
CHART 1 - Comparison of studies for the creation and standardization of animal experiments for SLNB of the stomach.

\begin{tabular}{|c|c|c|c|c|}
\hline AUTHORS & Méndez et al. & Kim et al. & Torres de Melo & Alves et al. \\
\hline CARACTERISTICS & $2003^{32}$ & $2008^{34}$ & $2010^{33}$ & 2012 (This study) \\
\hline Animal & Swine & rabbits & dogs (female) & Rabbits (male) \\
\hline Sample (N) & 4 & 7 & 25 & 32 \\
\hline Method of SLNB & Combined & Combined & Combined & Combined \\
\hline Site of puncture & $\begin{array}{l}\text { Submucosa } \\
\text { (local ND) }\end{array}$ & $\begin{array}{l}\text { Body subserosa } \\
5 \mathrm{~cm} \text { from the } \\
\text { small gastric curve }\end{array}$ & $\begin{array}{l}\text { Anthro seromuscular in } \\
\text { the small gastric curvature, } \\
1 \mathrm{~cm} \text { from the pylorus }\end{array}$ & $\begin{array}{l}\text { Body subseroso at } \\
3.5 \mathrm{~cm} \text { of the small } \\
\text { gastric curve }\end{array}$ \\
\hline $\begin{array}{l}\text { Substances injected } \\
\text { (quantity in } \mathrm{ml} \text { ) }\end{array}$ & $\begin{array}{l}\text { DTPA with AD }(0.1 \mathrm{ml} \\
\qquad 7.4 \mathrm{MBq})+1 \% \\
\text { isosulfan blue }(0.1 \mathrm{ml})\end{array}$ & $\begin{array}{l}\text { NFM }(0.1 \mathrm{ml}) \text { and } \\
1 \% \text { isosulfan } \\
\text { blue }(0.1 \mathrm{ml})\end{array}$ & $\begin{array}{l}99 \mathrm{~m} \mathrm{Tc} \text { with phytate }(0.2 \\
\mathrm{ml} / 19 \mathrm{MBq}) \text { and patent } \\
\text { blue } 2.5 \%(0.2 \mathrm{ml})\end{array}$ & $\begin{array}{c}99 \mathrm{~m} \mathrm{Tc} \text { with phytate } \\
(0.1 \mathrm{ml} / 7,4 \mathrm{MBq})+\text { patent } \\
\text { blue } 2.5 \%(0.2 \mathrm{ml})\end{array}$ \\
\hline Puncture at the same point & Single & $\begin{array}{c}\text { Separated / in } \\
\text { sequence }\end{array}$ & $\begin{array}{c}\text { Separated / > } 20 \text { min between } \\
\text { punctures }\end{array}$ & separated / in sequence \\
\hline $\begin{array}{l}\text { Evaluation time of suspect } \\
\text { lymph nodes }\end{array}$ & $5-10 \mathrm{~min}$ & $3-4.2 \mathrm{~min} *$ & $0,5,10,15,20$ and $40 \min ^{* *}$ & 5,10 and $20 \mathrm{~min}$ \\
\hline Lymphadenectomy time & $5-10 \mathrm{~min}$ & ND & after $40 \mathrm{~min}$ & after $20 \mathrm{~min}$ \\
\hline $\begin{array}{c}\text { Method of identification } \\
\text { of lymphatic tissue }\end{array}$ & None & $\begin{array}{l}\text { Histological study } \\
\text { Hematoxylin-eosin }\end{array}$ & None & $\begin{array}{l}\text { Histological study } \\
\text { Hematoxylin-eosin }\end{array}$ \\
\hline $\begin{array}{l}\text { Identification of LN in the } \\
\text { sample radiolabelled colloid/ } \\
\text { dye (\%) }\end{array}$ & ND & $\begin{array}{c}\text { ND } \\
\text { Combined methods } \\
=100 \%\end{array}$ & $80 \% / 96 \%$ & $\begin{array}{c}84.37 \% / 93.5 \% \\
(\text { Combined methods }= \\
93.75 \%)\end{array}$ \\
\hline Total $\mathrm{N}^{\circ}$. of LN identified & $\begin{array}{c}8 \mathrm{LN} \text { radiativo e } 6 \mathrm{LN} \\
\text { azul*** }\end{array}$ & $* * * *$ & $\begin{array}{c}27 \text { radioactive } \mathrm{LN}+39 \text { blue } \\
\mathrm{LN} * * * *\end{array}$ & $\begin{array}{l}70 \mathrm{LN} \text { (combined } \\
\text { methods) }\end{array}$ \\
\hline Mean $\mathrm{N}^{\circ}$. of LN per animal & ND & $* * * *$ & 1.08 radioactive / 1.56 blue & $\begin{array}{c}2.19 \text { lymph nodes/animal } \\
\text { (combined methods) }\end{array}$ \\
\hline $\begin{array}{l}\text { Most frequent location } \\
\text { of LN (frequency \%) }\end{array}$ & Celiac region & ND & $\begin{array}{l}\text { SL of the small curvature } \\
\text { and infrapylorics }\end{array}$ & $\begin{array}{l}\mathrm{LN} \text { of the region between } \\
\text { the esophagus and the } \\
\text { gastric fundus }\end{array}$ \\
\hline $\mathrm{N}^{\circ}$. of false positives & $\mathrm{NPC} * * * * *$ & $0 \%(\mathrm{ND})$ & $\mathrm{NPC} * * * * *$ & $22.22 \%$ \\
\hline Accuracy & $\mathrm{NPC}^{* * * * *}$ & $100 \%$ & $\mathrm{NPC}^{* * * * *}$ & $77.77 \%$ \\
\hline
\end{tabular}

Note: $\mathrm{LN}=$ lymph nodes; $\mathrm{DTPA}=$ Diethylenetriaminepentaacetic acid; $\mathrm{AD}=$ Aminodextran; $\mathrm{MBq}=$ Mega Becquerel; $99 \mathrm{~m}$ Tc $=$ Technetium $-99 \mathrm{~m} ; \mathrm{ND}=$ not determined; MFN = Magnetic fluorescent nanoparticles; NPC = Not possible to calculate due to lack of histological confirmation of the lymphod tissue; $*=$ They did not establish time, only waited for the lymph nodes to turn blue or fluorescent; $* *=$ Evaluations carried out over the times presented; $* * *=$ Criteria not defined to consider lymph nodes radioactive; $* * * *$ Cannot be evidenced due to absence of discription contained in the abstract and remainder of article written in Japanese (by symbols); $* * * * *=$ Lymph nodes not histologically confirmed.

compared with the histological confirmation (staining only method $-\mathrm{p}=0.7813$; gamma probe evaluation only method $-\mathrm{p}=1.0000$; combined methods $-\mathrm{p}=1.0000$ ).

Furthermore, the evaluation carried out at 20 minutes with combined methods or AzP only was the condition that exhibited the highest concordance with the histological study (ICC $=0.524$ ). (Exception: evaluations carried out up to ten minutes with the gamma probe, $\mathrm{ICC}=0.552$ ).

The 19 cases of false positive results occurred due to complications during the experiment, the most common of which occurred during the gastric wall punch and injection of $\mathrm{RC}$ and AzP (Table 3).

However, despite the complications, comparable to those that occurred in other studies conducted with human beings ${ }^{5,9,21}$, with the help of the radio-guided evaluation using hand-held gamma probe, lymph node identification proved possible in most of the cases $(93.75 \%)$.

The final BG (mean $=4.04 \mathrm{cps} ; \mathrm{SD}+/-5.9)$ did not 
interfere in the SLNB ${ }^{9}$

It was ascertained that the lymph nodes presented mean dimensions below $2 \mathrm{x}$ those found in human beings ${ }^{15}$. However, this did not impair the validation of this model, since the macroscopic aspect of the lymph nodes should not be used as a criterion for determining the presence of metastatic invasion, as already demonstrated by the occurrence of $69 \%$ of metastases in lymph nodes measuring less than $5 \mathrm{~mm}^{9,17}$.

Moreover, it is worth emphasizing that in two animals, it was suspected that three structures could be lymph nodes, even though they were not stained and radioactive. Two of these were lymph nodes (one located between the esophagus and gastric fundus and the other alongside the small curvature).

\section{Conclusion}

Animal model in rabbits is feasible, presents low cost in relation to the purchase of the animals, and low complexity, serving as the basis for the ethical execution of future studies related to the development and trial of new techniques, dyes and radiolabeled colloids for SLNB in the stomach. It also enables adequate training for professionals, particularly surgeons intending to carry out the procedure.

\section{References}

1. Gould EA, Winship T, Philbin PH, Herr HH. Observations on a sentinel nodell in cancer of the parotid. Cancer. 1960;13:77-8.

2. Cabanas RM. An Approach for the treatment of penile carcinoma. Cancer. 1977;39:456-66.

3. Morton DL, Wen DR, Wong JH, Economou JS, Cagle LA, Storm FK, Foshag LJ, Cochran AJ. Technical details of intraoperative lymphatic mapping for early stage melanoma. Arch Surg. 1992;127:392-9.

4. Tanis PJ, Nieweg OE, Olmos RAV, Rutgers EJT, Kroon BBR. History of sentinel node and validation of the technique - Review. Breast Cancer Res. 2001;3:109-12.

5. Hayashi H, Ochiai T, Mori M, Karube T, Suzuki T, Gunji Y, Hori S, Akutsu N, Matsubara H, Shimada H. Sentinel lymph node mapping for gastric cancer using a dual procedure with dye and gamma probe-guided techniques. J Am Coll Surg. 2003;196:68-74.

6. Veronesi U, Paganelli G, Galimberti V, Viale G, Zurrida S, Bedoni M, Costa A, De Cicco C, Geraghty JG, Luini A, Sacchini V, Veronesi P. Sentinel-node biopsy to avoid axillary dissection in breast cancer with clinically negative lymph-nodes. Lancet. 1997;349:1864-7.

7. Veronesi U, Viale G, Paganelli G, Zurrida S, Luini A, Galimberti V, Veronesi P, Intra M, Maisonneuve P, Zucca F, Gatti G, Mazzarol G, De Cicco C, Vezzoli D. Sentinel lymph node biopsy in breast cancer: ten-year results of a randomized controlled study. Ann Surg. 2010;251(4):595-600.

8. Yanagita S, Natsugoe S, Uenoson Y, Arigami T, Arima H, Kozono T, Funasako Y, Ehi K, Nakajo A, Ishigami S, Aikou T. Detection of micrometastases in sentinel node navigation surgery for gastric cancer. Surg Oncol. 2008;17:203-10.

9. Tangoku A, Seike J, Nakano K, Nagao T, Honda J, Yoshida T,
Yamai H, Matsuoka H, Uyama K, Goto M, Miyoshi T, Morimoto T. Current status of sentinel lymph node navigation surgery in breast and gastrointestinal tract. J Med Invest. 2007;54:1-18

10. Ozmen MM, Ozmen F, Aulfikaroglu B. Lymph nodes in gastric cancer. J Surg Oncol. 2008;98:476-81.

11. Kitagawa Y, Fujii H, Kumai K, Kubota T, Otani Y, Saikawa Y, Yoshida M, Kubo A, Kitajima M. Recent advances in sentinel node navigation for gastric cancer: a paradigm shift of surgical management. J Surg Oncol. 2005;90:147-52

12. Hiratsuka M, Miyashiro I, Ishikawa O, Furukawa H, Motomura K, Ohigashi H, Kameyama M, Sasaki Y, Kabuto T, Ishiguro S, Imaoka $\mathrm{S}$, Koyama H. Application of sentinel node biopsy to gastric cancer surgery. Surgery. 2001;129:335-40.

13. Ryu KW, Lee JH, Kim HS, Kim YW, Choi IJ, Bae JM. Prediction of lymph nodes metastasis by sentinel node biopsy in gastric cancer. Eur J Surg Oncol. 2003;29:895-9.

14. Kim M, Kim H, Jung G, Lee J, Choi S, Kang D, Roh M, Jeong J. Lymphatic mapping and sentinel node biopsy using 99mTC tin colloid in gastric cancer. Ann Surg. 2004;239(3):383-7.

15. Miwa K, Kinami S, Taniguchi K, Fushida S, Fujimura T, Nonomura A. Mapping sentinel nodes in patients with early-stage gastric carcinoma. Br J Surg. 2003;90:178-82.

16. Lee JH, Ryu KW, Kim CG, Kim SK, Choi IJ, Kim YW, Chang HJ, Bae JM, Hong EK. Comparative study of the subserosal versus submucosal dye injection method for sentinel node biopsy in gastric cancer. Eur J Surg Oncol. 2005;31:965-8.

17. Isozaki H, Kimura T, Tanaka, Satoh K, Matsumoto S. An assessment of the feasibility of sentinel lymph node-guided surgery for gastric cancer. Gastric Cancer. 2004;7:149-53.

18. Ichikura T, Sugasawa H, Sakamoto N, Yaguchi Y, Tsujimoto H, Ono S. Limited gastrectomy with dissection of sentinel node stations for early gastric cancer with negative sentinel node biopsy. Ann Surg. 2009;249(6):942-7.

19. Ohdaira H, Nimura H, Mitsumori N, Takahashi N, Kashiwagi H, Yanaga K. Validity of modified gastrectomy combined with sentinel node navigation surgery for early gastric cancer. Gastric Cancer. 2007;10(2):117-22.

20. Kitagawa Y, Kitano S, Kubota T, Kumai K, Otani Y, Saikawa Y, Yoshida M, Kitajima M. Minimally invasive surgery for gastric cancer - toward a confluence of two major streams: a review. Gastric Cancer. 2005;8:103-10.

21. Lee JH, Ryu KW, Kim CG, Kim SK, Lee JS, Kook MC, Choi J, Kim YW, Chang HJ, Bae J. Sentinel node biopsy using dye and isotope double tracers in early gastric cancer. Ann Surg Oncol. 2006;13(9):1168-74.

22. Orsenigo E, Tomajer V, Di Palo S, Albarello L, Doglioni C, Masci E, Viale E, Staudacher C. Sentinel node mapping during laparoscopic distal gastrectomy for gastric cancer. Staudacher. Surg Endosc. 2008;22:118-21.

23. Rabin I, Chikman B, Lavy R, Poluksht N, Halpern Z, Wassermann I, Gold-Deutch R, Sandbank J, Halevy A. The accuracy of sentinel node mapping according to $\mathrm{T}$ stage in patients with gastric cancer. Gastric Cancer. 2010;13:30-5.

24. Cheng LY, Xie ZY, Dai GR, Zhao WG. Preliminary experiences of application of sentinel lymph node navigation technique in early gastric cancer. Zhonghua Wai Ke Za Zhi. 2008;46(14):1076-9.

25. Ichikura T. Progress in sentinel node navigation surgery for gastric cancer. Nippon Geka Gakkai Zasshi. 2009;110(2):68-72.

26. Kitagawa Y, Kubota T, Kumai K, Otani Y, Saikawa Y, Yoshida M, Nakahara T, Kubo A, Kitajima M. Recent studies of sentinel lymph node. Multicenter prospective clinical trials of SN biopsy for gastric cancer. Gan To Kagaku Ryoho. 2005;32(5):695-8.

27. Kitagawa Y, Takeuchi H, Takagi Y, Natsugoe S, Terashima M, 
Murakami N, Fujimura T, Sakamoto J, Aikou T, Kitajima M. Prospective multicenter trial of sentinel node mapping for gastric cancer. J Clin Oncol. 2009;27(Suppl; abstr 4518):15S.

28. Kitagawa Y, Saikawa Y, Takeuchi H, Mukai M, Nakahara T, Kubo A, Kitajima M. Sentinel node navigation in early stage gastric cancer Updated data and current status. Scand J Surg. 2006;95:256-9.

29. Fagundes DJ, Taha MO. Modelo animal de doença: critérios de escolha e espécies de animais de uso corrente. Acta Cir Bras. 2004;19(1):59-65.

30. Calasans-Maia MD, Monteiro ML, Áscoli FO, Granjeiro JM. The rabbit as an animal model for experimental surgery. Acta Cir Bras. 2009;24(4):325-8

31. Schanaider A, Silva PC. Uso de animais em cirurgia experimental. Acta Cir Bras. 2004;19(4):441-7.

32. Méndez J, Wallace AM, Hoh CK, Vera DR. Detection of gastric and colonic sentinel nodes through endoscopic administration of $99 \mathrm{mTc}-$ DTPA-Mannosyl-Dextran in pigs. J Nucl Med. 2003;44(10):167781.

33. Torres de Melo JRM, Pinheiro LGP. Sentinel lymph node: importance in gastric cancer surgery and perspective of the application of an experimental model in canine. Arq Bras Cir. 2010;23(3):192-5.

34. Kim JS, Yoon TJ, Kim HK, Kim SS, Chae HS, Choi MG, Kim YJ, Yi GC, Cho YS. Sentinel lymph node mapping of the stomach using fluorescent magnetic nanoparticles in rabbits. Korean J Gastroenterol. 2008;51:19-24.

35. Alves JR, Lopes LR, Sasasaki T. Perioperative care in an animal model for training in abdominal surgery: it is necessary preoperative fasting? Acta Cir Bras. 2011;26(6):541-8.

36. Zhong SQ, Xu YD, Zhang YF, Zhang YF, Hai LS, Tang FC. Threedimensional structure of lymphatics in rabbit stomach. World $\mathrm{J}$ Gastroenterol. 1998;4(6):550-2.

37. Rodrígues-Alarcón C, Pérez E, Martín U, Rivera R, Hernández A, Vivo J, Beristain M, Usón J. Morfometría del esôfago abdominal y del estómago del conejo (Orycotolagus cuniculus). Aplicaciones a la cirurgía laparoscópica. Int J Morphol. 2010;28(1):27-31.

38. Ghoshal NG, Bal HS. Comparative morphology of the stomach of some laboratory mammals. Lab Anim. 1989;23:21-9.

39. Oliveira LR, Molinari SL, Natali MRM, Michelan AC, Scapinello C. Morphologic considerations about the wall of the glandular stomach of young rabbits (Oryctolagus cuniculus). Rev Chil Anat. 2001;19(3):253-8.

40. Landis JR, Koch GG. The measurement of observer agreement for categorical data. Biometrics. 1977;33:159-74.

\section{Acknowledgments}

To the biologists and technicians of the Surgical Technique and Experimental Surgery Laboratory/NMCE of the FCM from UNICAMP: William Adalberto Silva, Ana Cristina de Moraes, Miguel Luis Candido and Waldemir Benedito Costa.

\section{Correspondence:}

José Roberto Alves

Rua José Roberto Sagaz, 64

88302-560 Itajaí - SC Brasil

Tel.: (55 47)9110-0005 / 3344-2414 / 9601-2692

joserobertoalves1980@gmail.com

Received: July 10, 2012

Review: September 11, 2012

Accepted: October 15, 2012

Conflict of interest: none.

Financial source: FAPESP (São Paulo Research Foundation)

${ }^{1}$ Research performed at Surgical Technique and Experimental Surgery Laboratory, Medical Sciences School, State University of Campinas (UNICAMP), Brazil. Part of PhD thesis degree in Surgery Sciences. Tutor: Prof. Luiz Roberto Lopes. 